\title{
Erratum to: An Exploratory Study of Influences on Vulnerabilities to Family Violence Among Vietnamese Wives Who Marry South Korean
}

\author{
Suyeon Park ${ }^{1}$ (D) Merry Morash ${ }^{2}$
}

Published online: 2 September 2016

(C) Springer Science+Business Media Dordrecht 2016

\section{Erratum to: Crit Crim DOI 10.1007/s10612-016-9339-2}

Unfortunately there was an error in the title of the Published article. The corrected title of the article is given below and it has also been corrected in the original publication of the article.

"An Exploratory Study of Influences on Vulnerabilities to Family Violence Among Vietnamese Wives Who Marry South Korean Men”.

The online version of the original article can be found under doi:10.1007/s10612-016-9339-2.

Suyeon Park

spark018@plattsburgh.edu

Merry Morash

morashm@msu.edu

1 Department of Criminal Justice, SUNY Plattsburgh, Plattsburgh, NY 12901, USA

2 School of Criminal Justice, Michigan State University, East Lansing, MI 48824, USA 